\title{
Effects of the presence of litter on the composition of stream tadpoles' assemblages in an Atlantic Forest remnant of southeastern Brazil
}

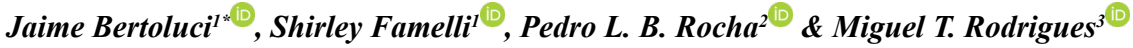 \\ ${ }^{1}$ Universidade de São Paulo, Escola Superior de Agricultura Luiz de Queiroz, Departamento de Ciências \\ Biológicas, Av. Pádua Dias, 11, 13418-900, Piracicaba, SP, Brasil. \\ ${ }^{2}$ Universidade Federal da Bahia, Instituto de Biologia, Departamento de Zoologia, Campus de Ondina, 40170- \\ 290, Salvador, BA, Brasil. \\ ${ }^{3}$ Universidade de São Paulo, Instituto de Biociências, Departamento de Zoologia, 05422-970, São Paulo, SP, \\ Brasil. \\ *Corresponding author: jaime.bertoluci@usp.br
}

BERTOLUCI, J., FAMELLI, S., ROCHA, P.L.B., RODRIGUES, M.T. Effects of the presence of litter on the composition of stream tadpoles' assemblages in an Atlantic Forest remnant of southeastern Brazil. Biota Neotropica 21(4): e20201147. https://doi.org/10.1590/1676-0611-BN-2020-1147

\begin{abstract}
Many tropical anurans use forest streams to deposit their eggs, but resource use and selection by tadpoles in tropical forests are poorly known. In the present research, we hypothesized that leaf litter and water depth affect tadpole assemblages due to adult habitat selection for oviposition and/or microhabitat selection by tadpoles. Fieldwork was carried out in the Estação Biológica de Boracéia, an Atlantic Rainforest reserve in São Paulo state, southeastern Brazil. We sampled tadpoles during a year using 40 double-entry funnel-traps distributed along four streams in the forest. Only leaf litter effects are species dependent. We discussed that habitat structure significance depends on the morphological and ecological adaptation to forage and avoid competition within the tadpole community.

Keywords: Amphibians; Aplastodiscus leucopygius; Bokermannohyla hylax; microhabitat selection; Scinax obtriangulatus, Phasmahyla cochranae; southeastern Brazil; tadpoles.
\end{abstract}

\section{Efeitos da presença de serapilheira na composição de assembleias de girinos de riacho em um remanescente de Mata Atlântica do sudeste do Brasil}

\footnotetext{
Resumo: Uma variedade de espécies de anuros tropicais usa riachos da floresta para depositar seus ovos, mas o uso e a seleção de recursos por girinos em florestas tropicais são pouco conhecidos. Na presente pesquisa, nossa hipótese era a de que a presença de serapilheira e a profundidade das poça dos riachos influenciam a presença de girinos devido à seleção de habitats de ovipostura pelos adultos e/ou seleção de micro-habitats pelos girinos. O trabalho de campo foi realizado na Estação Biológica de Boracéia, uma reserva de Mata Atlântica no estado de São Paulo, sudeste do Brasil. Amostramos girinos durante um ano usando 40 armadilhas-de-funil de dupla entrada distribuídas ao longo de quatro riachos na floresta. Apenas os efeitos da presença de serapilheira foram significativos Nós discutimos as relações entre a estrutura do habitat e características morfológicas, ecológicas e adaptações para procura de alimento e para evitar competição no interior da comunidade de girinos.

Palavras-chave: Anfibios; Aplastodiscus leucopygius; Bokermannohyla hylax; girinos; Phasmahyla cochranae; Scinax obtriangulatus; seleção de micro-habitat; sudeste do Brasil.
} 


\section{Introduction}

Anuran amphibians exhibit a combination of particular reproductive strategies that includes selective breeding sites, clutch characteristics, rate and duration of larval development, and eventually parental care (Haddad \& Prado 2005), linked to their spatial distribution and reproductive success (Haddad \& Sawaya 2000, Wells 2007). Tadpoles are generally found in water bodies suitable for their development and success that are selected by their parents (Wells 2007). In these water bodies it is expected that local factors related to habitat structure and resource quality explain tadpole richness, diversity and development (Savage 1952, Stoler \& Relyea 2013b, Almeida et al. 2015).

Generally, habitat use discerns among tadpoles of different species (Kopp \& Eterovick 2006), as variation in morphology, physiology, and phenology impose restrictions on the way tadpoles explore the microhabitats (Fatorelli \& Rocha 2009). When sharing the same site, tadpole assemblages are organized to avoid competition while keeping safe from predators (Heyer 1976). Most tadpoles are filter-feeders, which can impose high levels of competition to species sharing the same pond (Fatorelli \& Rocha 2009), unless there is a partitioning of resources in terms of space, time, or food (Heyer 1976). For instance, tadpoles can differ in the foraging mode using the water surface, mid-water, or water bottom (Heyer 1973, 1976).

Resource quality also affects tadpole morphology and development, as larvae scratch the substrate and ingest nutrients directly by litter consumption or grazing microbial communities (Savage 1952, Stoler \& Relyea 2013b). Leaf litter inputs are dominant energy and nutrient resources for tadpoles and yet can reduce their predation rate, acting as a refuge (Stoler \& Relyea 2013a). Further, vegetation composition affects litter quality, which induces phenotypic and morphological changes on the consumers, potentially altering their fitness (Stoler \& Relyea 2013b).

Many abiotic and biotic factors can influence the structure of tropical tadpole assemblages (Borges Júnior \& Rocha 2013, Marques et al. 2019). A variety of tropical anurans use forest streams to deposit their eggs, and there are few reports on how changes in microhabitat influence tadpoles (Kopp \& Eterovick 2006, Kopp et al. 2006, Caldas et al. 2019). In the Atlantic Rainforest, the composition of stream tadpoles' assemblages is influenced by abiotic and biotic factors (Eterovick \& Barata 2006, Kopp \& Eterovick 2006, Bertoluci et al. 2013, Jordani et al. 2017), making species more prone to resource partitioning (Melo et al. 2018). Atlantic rainforest streams are often composed of interconnected shallow puddles with rocky bottom, whose depth and presence of litter vary greatly. These are the main habitats to stream tadpoles, so it is expected physical characteristics of puddles influence tadpole occurrence. In the present study, we hypothesized that water depth and/or the presence of leaf litter affect the species composition of tadpoles' assemblages in Atlantic rainforest streams.

\section{Material and Methods}

\section{Study site and data collection}

Fieldwork was carried out in the Estação Biológica de Boracéia (EBB), an Atlantic Rainforest reserve with 16,450 ha located at $900 \mathrm{~m}$ a.s.l. in one of the wettest regions of São Paulo state, southeastern Brazil (Setzer 1946) (Figure 1). Rainfall was irregularly distributed during the study period, with total precipitation of $1,747.3 \mathrm{~mm}$ and rainy season extending from September to March (Bertoluci et al. 2013). The area is covered by Dense Ombrophylous Forest, with an understory relatively opened but denser along streams (Bertoluci \& Rodrigues 2002).

We selected four streams to obtain data on the association of microhabitat variables and the species composition of tadpole assemblage (sites R1 to R4 in Bertoluci \& Rodrigues 2002; Figure 1). R1 corresponds to a small stream ( $60 \mathrm{~m}$ long, $1.3 \mathrm{~m}$ wide, $22 \mathrm{~cm}$ maximum depth) located in the primary forest and containing interconnected rocky or muddy puddles with organic matter in decomposition, mainly dead leaves and sticks. R2 is a small stream $(50 \mathrm{~m}, 1.8 \mathrm{~m}, 27 \mathrm{~cm})$ in the forest edge. R3 is a small stream $(96 \mathrm{~m}, 2 \mathrm{~m}, 32 \mathrm{~cm})$ in the primary forest with interconnected puddles with a rocky, sandy bottom and dead leaves. $\mathrm{R} 4$ is a small stream $(91 \mathrm{~m}, 2.4 \mathrm{~m}, 30 \mathrm{~cm})$ inside the forest; its bed is mainly rocky, but some puddles have sand and dead leaves (Table 1).

Tadpole sampling were carried out with 40 double-entry funnel-traps constructed with two 2-L plastic bottles, which result in approximately 1.5-L traps; traps were entirely submerged at the bottom of the stream puddles (Figure 2). We estimated the relative abundances of tadpoles in 40 traps distributed along the selected streams (10 traps in each stream). Sampling was carried out monthly with traps kept active during 72 hours per month from September 1993 to September 1994. The species abundance was calculated by summing the total of all individuals collected through the year. The microhabitat of each plot was characterized based on two variables: water depth (measured with a ruler in the deepest point of each stream puddle, where the trap was positioned; depth did not vary significantly along the year) and presence or absence of leaf litter ( 0 or 1$)$. We built a matrix crossing the tadpole species and their microhabitat features to conduct an ordination or gradient analysis.

\section{Data analysis}

In order to evaluate the effects of microhabitat variables on the tadpole composition, we used PerMANOVA (bray-curtis method), with presence/absence of litter as fixed factor and stream depth as covariate. Considering that our sampling observations are not independent (pseudo-replication) we used the stream ID (R1, R2, R3, and R4) to restrict the permutations in PerMANOVA, using the argument "strata" in the function "adonis" in R. We plotted the variables and species using NDMS. This analysis was performed using R 3.6.3 version. Significance level adopted in the study was 0.05 .

\section{Results}

Four anuran tadpole species known to inhabit streams were captured in our study in EBB: Aplastodiscus leucopygius $(N=146)$, Bokermannohyla hylax (139), Scinax obtriangulatus (89) (Hylidae), and Phasmahyla cochranae (2) (Phyllomedusidae) (Figure 3). The analysis of microhabitat use and selection was performed with only 38 out of the 40 initial traps because two traps were empty. The number of tadpoles per trap varied from 0 to 79 , and the abundance distributions for all species was very skewed (Table 2). Tadpoles of different species shared the same trap in $37 \%$ (Figure 4), mostly with B. hylax and A. leucopygius. These two species were captured together in $32 \%$ of the samplings. On the other hand, only two tadpoles of $S$. obtriangulatus were observed sharing the same trap with tadpoles of $B$. hylax. One tadpole of S. obtriangulatus was observed with 26 tadpoles of B. hylax, 
Presence of litter affects stream tadpole assemblages

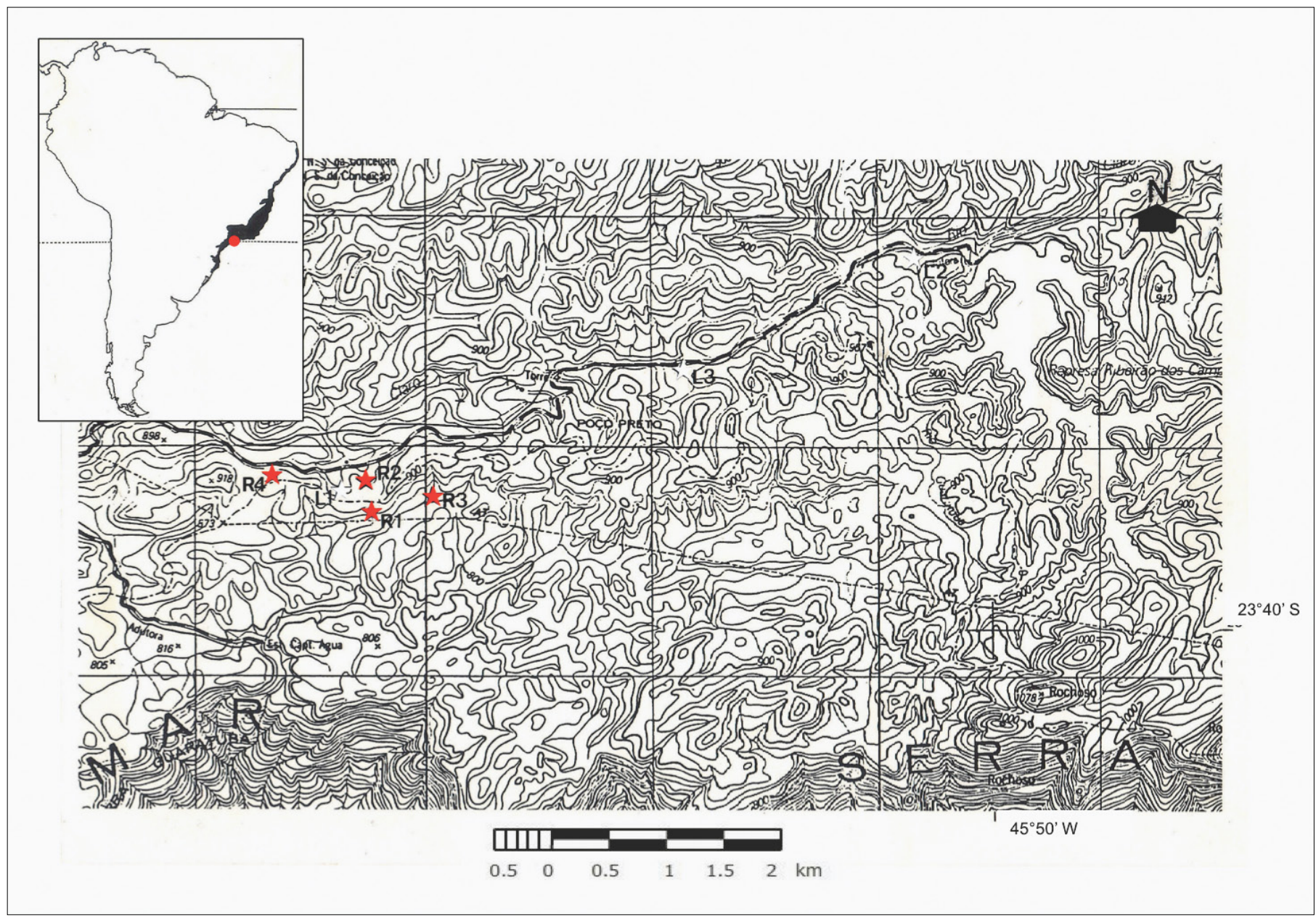

Figure 1. Location of the study site in the Atlantic rainforest (red circle) and of streams R1 to R4 in the study site (red stars).

Table 1. Characteristics of the four streams used for the study of tadpoles in a remnant of the in Atlantic Forest at the Estação Biológica de Boracéia, São Paulo state, southeastern Brazil.

\begin{tabular}{lcccc}
\hline Stream & R1 & R2 & R3 & R4 \\
\hline Length (m) & 60 & 50 & 96 & 91 \\
Width (m) & 1.3 & 1.8 & 2 & 2.4 \\
Depth (cm) & 22 & 27 & 32 & 30 \\
Bed & rocky/muddy & sandy/rocky & rocky/sandy & rocky/sandy \\
Location & Primary forest & Forest edge & Inside the forest & Inside the forest \\
\hline
\end{tabular}

and in another occasion one tadpole was captured with two tadpoles of $B$. hylax. Phasmahyla cochranae tadpoles was observed sharing the same trap with one tadpole of $B$. hylax, and on another occasion, it was found in the same trap with one tadpole of A. leucopygius (Figure 4).

Using PerMANOVA we detected effect of presence/absence leaf litter on the composition of tadpole community $\left(\mathrm{F}_{3,37}=9.3238, p=\right.$ $0.030)$ but not of the stream depth $\left(\mathrm{F}_{3,37}=1.4364, p=0.677\right)$ (Figure 5).

\section{Discussion}

The tadpole assemblages studied in EBB showed partitioning organization with habitat structure discerning among tadpole species. These findings corroborate other studies in the Atlantic rainforest, like those of Jordani et al. (2017), which shows that habitat type (lentic or lotic) influences the structure of the assemblages, and of Kopp \& Eterovick (2006), which demonstrates that patterns of species distributions are due to environmental and stochastic factors rather than by predation. According to Kopp et al. (2006), the choice of shallow or deep areas in the water column can be a strategy to avoid predation or interspecific competition. In the present study, we did not find a correlation with puddle depth, but species were associated with the presence of litter. An early description of $S$. obtriangulatus in Boracéia witnessed tadpoles of this species using the bottom of the puddle in a small stream in the forest (Heyer et al. 1990). Due to their anteroventral mouth tadpoles of $P$. cochranae forage swimming in the water surface and sometimes float motionless at mid-water (Leão-Pires 


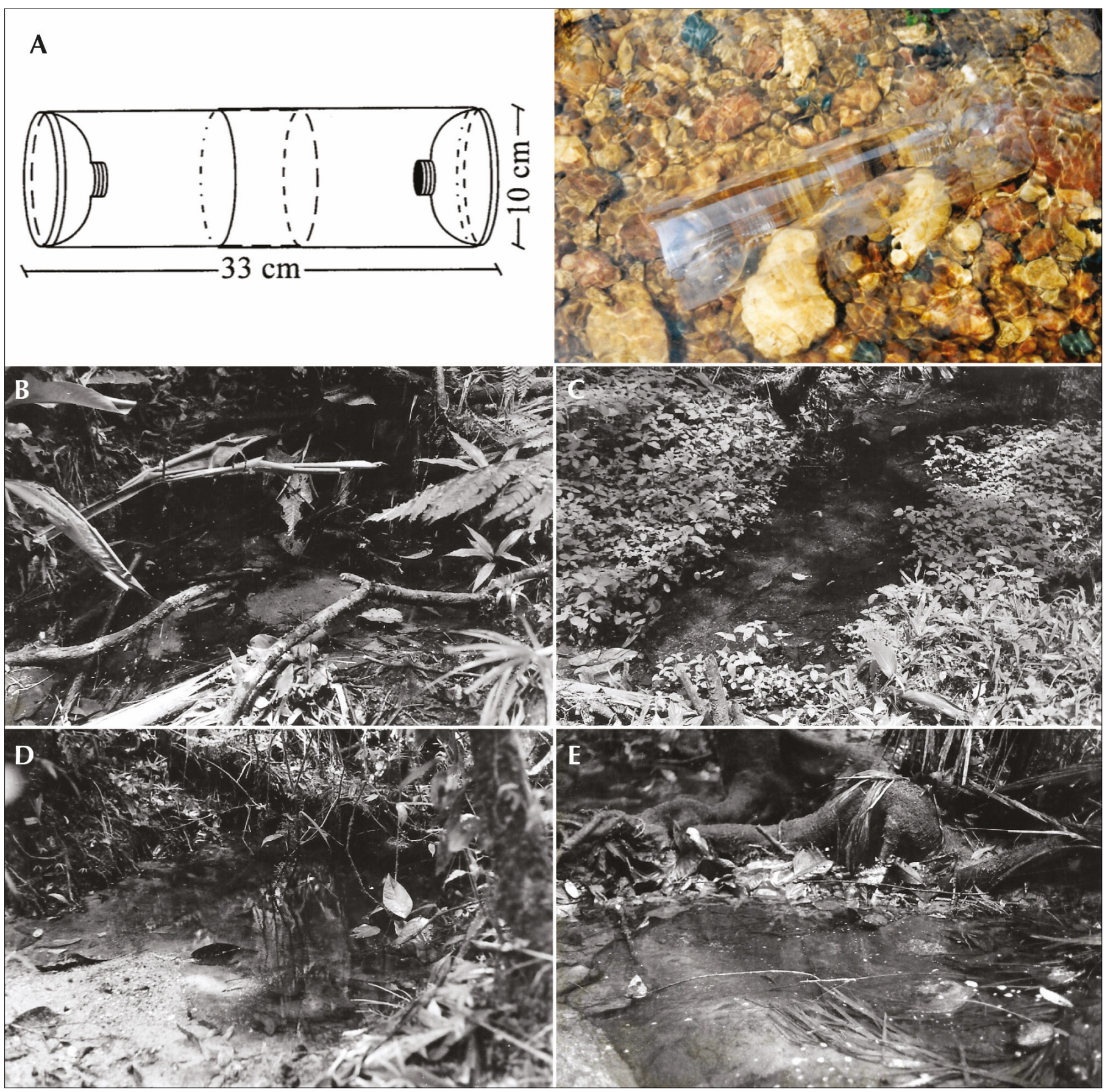

Figure 2. (A) Double-entry funnel-trap used in tadpole sampling (this photo was not taken at the study site). (B-E) Puddles in the streams R1 to R4, all of them containing leaf litter in the bottom.

et al. 2017). Puddle depth did not influence the occurrence of Phasmahyla nordestinus tadpoles, suggesting a strategy to avoid competition or a response to unpredictable temporary aquatics habitats, limiting the degree of specialization for resources in the Brazilian semi-arid, an environment subjected to water scarcity and irregularities (Caldas et al. 2019). Phasmahyla cochranae tadpoles present schooling and aggregation behavior associated with daylight (Leão-Pires et al. 2017). In the present study, only two tadpoles of $P$. cochranae were captured and on different occasions, which is easily explained by the fact that the traps were set at the bottom of the stream, reducing the probability of capturing non-benthic tadpoles. Apart from daylight, tadpole aggregation behavior is linked to water transparency, temperature, and other characteristics not investigated in the present study (Branch 1983, Spieler 2003). However, it is known that tadpoles of $P$. cochranae and $S$. obtriangulatus are more active during the day (Carvalhoe-Silva 1986, Leão-Pires et al. 2017). Behavior shift can also be a strategy to avoid overlapping and interspecific competition as well to assure protection against predators (Carlson \& Langkilde 2013).

Diel activity behavior can be a sign of tadpole assemblage organization and partitioning (Heyer 1976). Bokermannohyla hylax and A. leucopygius tadpoles are also more active at night presumably to avoid predators 

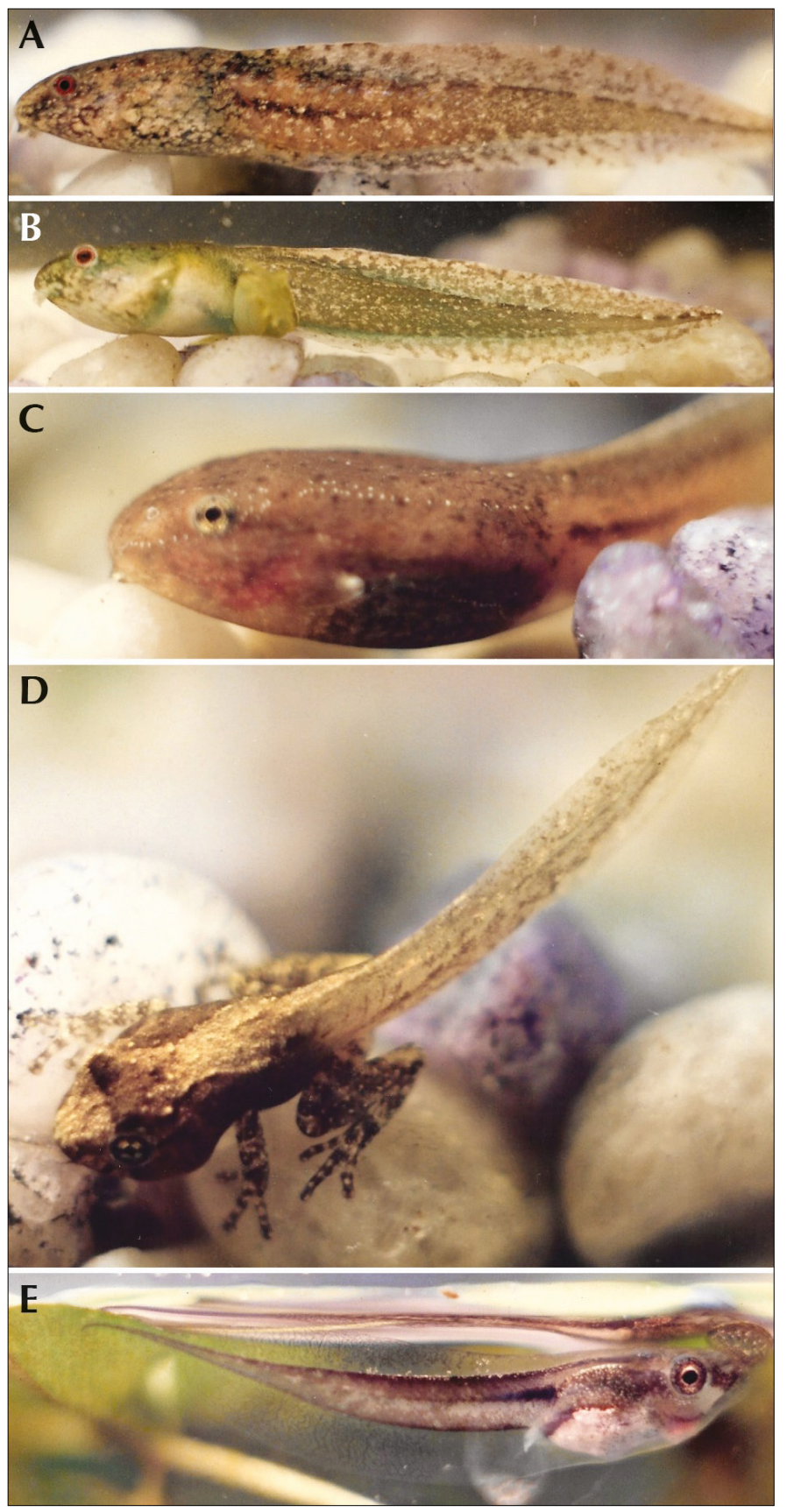

Figure 3. Tadpoles collected in this study. (A-B) Aplastodiscus leucopygius (cryptic form and tadpole changing to the green coloration of adults; note the red eyes), (C) Bokermannohyla hylax (note the unpigmented spiracle), (D) Scinax obtriangulatus (advanced stage of metamorphosis), (E) Phasmahyla cochranae (note the anterodorsal funnel-shaped oral disc).

(Bertoluci 2002, Gomes and Peixoto 2002). These two species show specialized reproductive modes associated with forest streams (Haddad \& Prado 2005, Gomes \& Peixoto 2002). Together they were the most abundant tadpoles in our sampling and often shared the same trap. The dark chocolatebrown coloration of $B$. hylax tadpoles shows an advantage when seeking cover among the leaf litter, rocks, and mud in the streambed (Bertoluci et al. 2003). This could likewise represent an advantage for A. leucopygius with a cryptic coloration that hides under litter and rocks (Gomes \& Peixoto 2002), except in the advanced stages of metamorphosis, when tadpoles turn to green (Figure 3A-B).
Differences in the habitat structure used by tadpoles is perhaps a combination between oviposition site selection by adults and microhabitat selection by tadpoles, owing to evidences that each lifehistory stage evolves independently (Sherratt et al. 2017). Habitat structure, such as leaf litter cover and depth, humidity, vegetation, and canopy cover, offer insights into amphibian richness and abundance (Jongsma et al. 2014, Marques et al. 2019). Generally, oviposition sites will be near habitats suitable for mating by the adults, yet adult anuran and tadpoles may use distinct spatial resources during their complex life cycle (Haddad \& Sawaya 2000, Rudolf \& Rödel 2005, Wells 2007). Aplastodiscus leucopygius has a long breeding season, benefiting from the rain for reproduction (Bertoluci \& Rodrigues 2002). This species shows a complex courtship with males guiding females to subterranean nests previously constructed by them (Haddad \& Sawaya 2000). Tadpoles then scape from the nests chambers when it floods by the rise in the pond's water level caused by heavy rains and reach the water bodies in either streams or temporary ponds (Haddad \& Prado 2005). This adaptation suggests some tolerance and flexibility of tadpoles to cope with external unpredictable factors influenced by hydrological cycles, water depth, or litter availability. In any case, high specializations to habitat structure represent disadvantageous to the species survivorship in unpredictable environments (Ultsch et al. 1999).

Tadpoles of different species show different habitat exploration strategies associated with their physiology, morphology, and phenology (Zimmerman \& Simberloff 1996). A combination of evolutionary processes is involved either in the choice of oviposition sites by adults or in the resource use by tadpoles, being survival their end goal. Yet anuran mortality is highest during the larvae stage (Heyer 1973). Anurans in the Atlantic Rainforest are known for their specialized reproductive modes (Haddad \& Prado 2005). The four species studied here showed various adaptations to their microhabitats, represented by distinct evolutionary processes that guarantee their safe development. In other words, each species has its own evolutionary strategy to ensure larval phase and adult recruitment success, a combination of adult selection for breeding and oviposition sites and tadpole strategies to forage, hide, and escape from predators and avoid competitors. Habitat use will then depend on the resources available when larvae emerge from eggs, as they have limited locomotor ability at this stage (Heyer 1976).

Tadpoles play essential roles in tropical streams not only as prey but also producing substantial amounts of egested particles (still understudied) that are critical nutrient sources in streams (Ramamonjisoa \& Natuhara 2018, Iwai et al. 2009), and so they act as abiotic and biotic elements of aquatic communities (Stoler et al. 2016). Additional comparison between lentic and lotic habitats could show distinct outcomes as consumers may have different responses to litter in ponds and wetlands that retain litter for extended periods compared to streams (Melo et al. 2017, Stoler et al. 2016, Stoler \& Relyea 2016).

We concluded that presence/absence of leaf litter has an effect on the composition of stream tadpoles' assemblages. Anyhow, the presence of vegetation can be an important variable influencing tadpole richness of both ponds and streams (Kopp et al. 2006). Vegetation type and presence were not investigated in the present study, but their influence could be an important component in the species composition (Kopp \& Eterovick 2006, Melo et al. 2018). Future studies are recommended to comprehend each species' response to different types of resources, such as vegetation, water rate, streambed, daylight, and in lentic habitats, considering the species morphology and phylogeny. 
Bertoluci, J., Famelli, S. et al.

Table 2. Captures of tadpoles of four anuran species in 38 traps in Atlantic Forest streams at the Estação Biológica de Boracéia, southeastern Brazil. Values are discriminated for sampling unities with $(n=27)$ and without $(n=11)$ litter. Values are presented as: (total number collected; number of plots where the species occurred) and mean \pm standard deviation.

\begin{tabular}{ccccc}
\hline Plots & Scinax obtriangulatus & Bokermannohyla hylax & Aplastodiscus leucopygius & Phasmahyla cochranae \\
\hline With & $(84 ; 3)$ & $(114 ; 19)$ & $(136 ; 18)$ & $(1 ; 1)$ \\
litter & $3.1 \pm 15.19$ & $4.2 \pm 6.00$ & $5.0 \pm 6.6$ & $0.0 \pm 0.19$ \\
Without & $(5 ; 2)$ & $(25 ; 10)$ & $(10 ; 5)$ & $(1 ; 1)$ \\
litter & $0.5 \pm 1.21$ & $2.3 \pm 1.62$ & $0.9 \pm 1.2$ & $0.1 \pm 0.30$ \\
Total & $(\mathbf{8 9} ; \mathbf{5})$ & $\mathbf{( 1 3 9 ; 2 9 )}$ & $\mathbf{( 1 4 6 ; 2 3 )}$ & $\mathbf{( 2 ; 2 )}$ \\
\hline
\end{tabular}

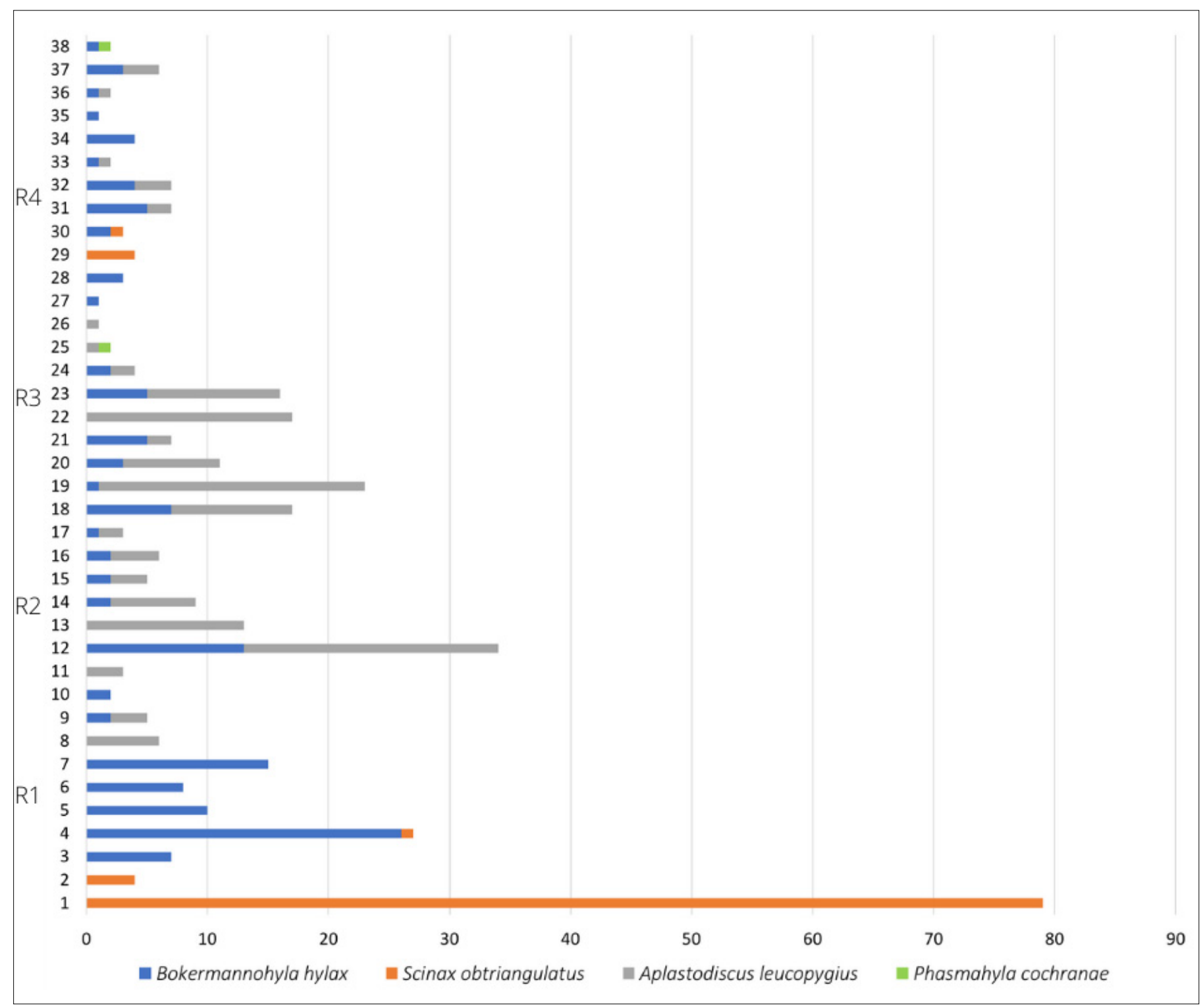

Figure 4. Tadpole abundances of four anuran species in 38 traps distributed in four streams of an Atlantic rainforest remnant of southeastern Brazil.

\section{Acknowledgments}

We thank FAPESP for a grant to JB (process number 96/6701-3). This study was supported in part by the Coordenação de Aperfeiçoamento de Pessoal de Nível Superior - Brasil (CAPES) - Finance Code 001. CNPq provided productivity grants to JB, PLBR, and MTR. PLBR was supported by a scholarship from Fundação de Amparo à Pesquisa do Estado da Bahia during his association with the project. Thanks are due to Gabriel Skuk (in memorian), for suggesting the design of the funnel traps, and to Cybele Araújo, for de drawing of the trap.

\section{Author Contributions}

Jaime Bertoluci: Substantial contribution in the concept and design of the study, Providing resources, Data collection, Contribution to data 


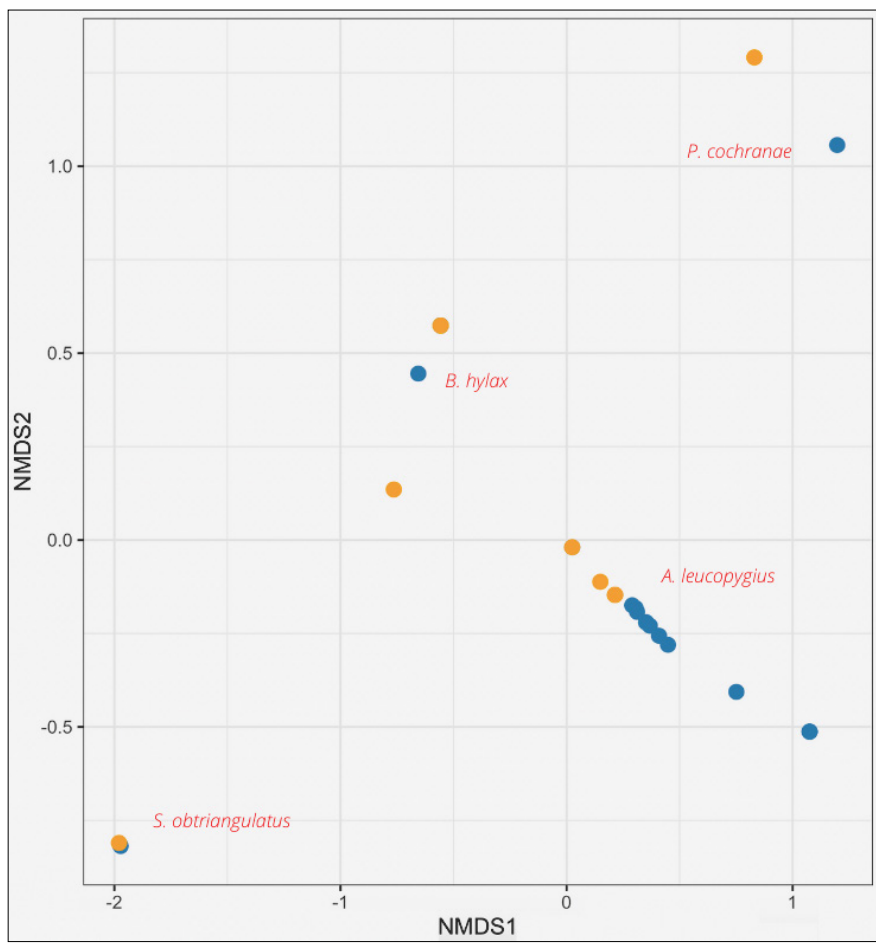

Figure 5. Biplot showing the systematic change of tadpole community composition (relative abundance) with change in water depth and presence of leaf litter in the streams studied at Estação Biológica de Boracéia, southeastern Brazil. Blue and orange circles represent observations with and without leaf litter, respectively.

analysis and interpretation, Contribution to manuscript preparation, Contribution to critical revision, adding intellectual content

Shirley Famelli: Contribution to data analysis and interpretation, Contribution to manuscript preparation, Contribution to critical revision, adding intellectual content

Pedro L. B. Rocha: Contribution to data analysis and interpretation, Contribution to manuscript preparation, Contribution to critical revision, adding intellectual content

Miguel T. Rodrigues: Substantial contribution in the concept and design of the study, Providing resources, Contribution to manuscript preparation, Contribution to critical revision, adding intellectual content.

\section{Conflicts of Interest}

We have no conflicts of interest.

\section{References}

ALMEIDA, A.P., RODRIGUES, D.J., GAREY, M.V. \& MENIN, M. 2015. Tadpole richness in riparian areas is dby niche-based and neutral processes. Hydrobiologia 745(1):123-35.

BERTOLUCI, J. 2002. Diel activity of the tadpoles of Hyla hylax (Anura: Hylidae) at Boracéia, southeastern Brazil. Phyllomedusa 1(1):41-43.

BERTOLUCI, J. \& RODRIGUES, M.T. 2002. Seasonal patterns of breeding activity of Atlantic Rainforest anurans at Boracéia, southeastern Brazil. Amphibia-Reptilia 23(2):161-67.

BERTOLUCI, J., ROCHA, P.L. \& RODRIGUES, M.T. 2013. Field evidence of coupled cycles of arthropod predator-tadpole prey abundance in six aquatic systems of an Atlantic Rainforest site in Brazil. Herpetol. J. 23(1):63-66.

BERTOLUCI, J., XAVIER, V. \& CASSIMIRO, J. 2003. Description of the tadpole of Hyla hylax Heyer, 1985 (Anura, Hylidae) with notes on its ecology. Amphibia-Reptilia 24(4):509-514.
BERTOLUCI, J., SAWAKUCHI, H.O., ORTIZ, C., BRASSALOTI, R.A., RIBEIRO-JÚNIOR, J.W. \& FAMELLI, S. 2021. Anuran fauna of the Parque Estadual Carlos Botelho - Núcleo Sete Barras, southeastern Brazil: species composition, use of breeding sites, and seasonal patterns of breeding activity. Biota Neotropica 21(1): e20201082.

BORGES JÚNIOR, V. \& ROCHA. 2013. Tropical tadpoles assemblages: which factors affect their structure and distribution? Oecol. Aust. 17(2): 217-228.

BRANCH, L.C. 1983. Social behavior of the tadpoles of Phyllomedusa vaillanti. Copeia 1983(2):420-428.

CALDAS, F.L.S., SILVA, B.D., DE-CARVALHO, C.B., SANTANA, D.O., GOMES, F.F.A, CAVALCANTI, L.B.Q., SANTOS, R.A. \& FARIA, R.G. 2019. Factors determining the spatial and temporal variation in the abundance of Pithecopus nordestinus tadpoles (Anura: Phyllomedusidae) in a semi-arid Brazilian environment. Salamandra 55(4):253-263.

CARLSON, B.E. \& LANGKILDE. T. 2013. A common marking technique affects tadpole behavior and risk of predation. Ethology 119(1):167-177.

CARVALHO-E-SILVA, S.P. 1986. Girinos de espécies do gênero Ololygon pertencentes ao grupo 'catharinae', no Estado do Rio de Janeiro. M.Sc. Dissertation. Universidade Federal do Rio de Janeiro, Brazil. 77 p.

ETEROVICK, P.C. \& BARATA, I.M. 2006. Distribution of tadpoles within and among Brazilian streams: the influence of predators, habitat size and heterogeneity. Herpetologica 62(4):365-377.

ETEROVICK, P.C., LAZAROTTI, I., FRANCO, B.P., \& DIAS, C.J. 2010. Seasonal variation of tadpole spatial niches in permanent streams: the roles of predation risk and microhabitat availability. Austral Ecol. 35(8): 879-887.

FATORELLI, P. \& ROCHA, C.F.D. 2009. O que molda as guildas de girinos tropicais? Quarenta anos de busca de padrões. Oecol. Bras. 12(4):733-742.

GOMES, M.R., \& PEIXOTO, O.L. 2002. O girino de Hyla leucopygia Cruz \& Peixoto, 1987 (Amphibia, Anura, Hylidae). Bol. Mus. Biol. Mello Leitão 13:17-25.GRELLE, C.E.V., RAJÃO, H. \& MARQUES, M.C.M. 2021. “The Future of the Brazilian Atlantic Forest." In The Atlantic Forest, edited by M.C.M. Marques and C.E.V. Grelle, 487-503. Cham: Springer International Publishing. https://doi.org/10.1007/978-3-030-55322-7_23.

HADDAD, C.F.B. \& PRADO, C.P.A. 2005. Reproductive modes in frogs and their unexpected diversity in the Atlantic forest of Brazil. BioScience 55(3):207-217.

HADDAD, C.F.B. \& SAWAYA, R.J. 2000. Reproductive modes of Atlantic forest hylid frogs: a general overview and the description of a new mode. Biotropica 32(4b): 862-871HEYER, W.R. 1973. "Ecological Interactions of Frog Larvae at a Seasonal Tropical Location in Thailand." Journal of Herpetology. https://doi.org/10.2307/1562868.

HEYER, W.R. 1973. Ecological interactions of frog larvae at a seasonal tropical location in Thailand. J. Herpetol. 7(4):337-361.

HEYER, W.R. 1976. Studies in larval amphibian habitat partitioning. Smithson. Contr. Zool. 242:1-27.

HEYER, W.R., RAND, A.S., CRUZ, C.A.G, PEIXOTO, O.L. \& NELSON, C.E. 1990. Frogs of Boracéia. Arq. Zool. 31(4):231-410.

IWAI, N., PEARSON, R.G. \& ALFORD, R.A. 2009. Shredder-tadpole facilitation of leaf litter decomposition in a tropical stream. Freshw. Biol. 54(12):2573-2580.

JONGSMA, G.F.M., HEDLEY, R.W., DURÃES, R. \& KARUBIAN, J. 2014. Amphibian diversity and species composition in relation to habitat type and alteration in the Mache-Chindul Reserve, northwest Ecuador. Herpetologica 70(1):34-46.

JORDANI, M.X., MELO, L.S.O., QUEIROZ, C.S., ROSSA-FERES, D.C. \& GAREY, M.V. 2017. Tadpole community structure in lentic and lotic habitats: richness and diversity in the Atlantic rainforest lowland. Herpetol. J. 27(3):299-306.

JORDANI, M.X., MOUQUET, N., CASATTI, L., MENIN, M., ROSSA-FERES, D.C. \& ALBERT, C.H. 2019. Intraspecific and interspecific trait variability in tadpole meta-communities from the Brazilian Atlantic rainforest. Ecol. Evol. 9(7): 4025-4037.

KOPP, K. \& ETEROVICK, P.C. 2006. Factors influencing spatial and temporal structure of frog assemblages at ponds in southeastern Brazil. J. Nat. Hist. 40(29-31):1813-1830. 
KOPP, K., WACHLEVSKI, M. \& ETEROVICK, P.C. 2006. Environmental complexity reduces tadpole predation by water bugs. Can. J.Zool. 84(1):136-140.

LEÃO-PIRES, T.A., GIARETTA, A. \& SAWAYA, R.J. 2017. The diurnal aggregation behavior in Phasmahyla cochranae tadpoles (Anura: Phyllomedusidae). Basic Appl. Herpetol. 31:117-123.

LIMA, R.C.L., DIAS, J.E.M., LIMA, N.G.S., TORRES, P.F. \& ETEROVICK, P.C. 2015. Escape response of tadpoles of two species of Bokermannohyla (Anura, Hylidae) to simulated threat. J. Herpetol. 49(2):176-183.

MARQUES, N.C.S., RATTIS, L. \& NOMURA, F. 2019. Local environmental conditions affecting anuran tadpoles' microhabitat choice and morphological adaptation. Mar. Freshwater Res. 70(3):395-401.

MCCUNE, B., GRACE, J.B. \& URBAN, D.L. 2002. Analysis of Ecological Communities. MjM Software Design, Gleneden Beach. Oregon, MJM Software Design.

MELO, L.S.O., GAREY, M.V. \& ROSSA-FERES, D.C. 2018. Looking for a place: how are tadpoles distributed within tropical ponds and streams? Herpetol. Notes 11:379-386.

MELO, L.S.O., GONÇALVES-SOUZA, T., GAREY, M.V. \& CERQUEIRA, D. 2017. Tadpole species richness within lentic and lotic microhabitats: an interactive influence of environmental and spatial factors. Herpetol. J. 27 (4):339-345.

QUEIROZ, C.S., SILVA, F.R. \& ROSSA-FERES, D.C. 2015. The relationship between pond habitat depth and functional tadpole diversity in an agricultural landscape. R. Soc. open sc. 2:150165.

RAMAMONJISOA, N. \& NATUHARA, Y. 2018. Contrasting effects of functionally distinct tadpole species on nutrient cycling and litter breakdown in a tropical rainforest stream. Freshw. Biol. 63(2):202-213.

RUDOLF, V.H.W. \& RÖDEL, M.O. 2005. Oviposition site selection in a complex and variable environment: the role of habitat quality and conspecific cues. Oecologia 142:316-325.

SAVAGE, R.M. 1952. Ecological, physiological and anatomical observations on some species of anuran tadpoles. Proc. Zool. Soc. London 122(2):467-514.
SETZER, J. 1946. Atlas Climático e Ecológico do Estado de São Paulo. São Paulo: Comissão Interestadual da Bacia Parana-Uruguai/CESP.

SHERRATT, E., VIDAL-GARCÍA, M., ANSTIS, M. \& KEOGH, J.S. 2017. Adult frogs and tadpoles have different macroevolutionary patterns across the Australian continent. Nat. Ecol. Evol. 1:1385-1391.

SPIELER, M. 2003. Risk of predation affects aggregation size: a study with tadpoles of Phrynomantis microps (Anura: Microhylidae). Anim. Behav. 65(1):179-184.

STOLER, A.B. \& RELYEA, R.A. 2013a. Leaf litter quality induces morphological and developmental changes in larval amphibians. Ecology 94(7):1594-1603.

STOLER,A.B. \& RELYEA, R.A. 2013b. Bottom-up meets top-down: leaf litter inputs influence predator-prey interactions in wetlands. Oecologia 173(1):249-257.

STOLER, A.B. \& RELYEA, R.A. 2016. Leaf litter species identity alters the structure of pond communities. Oikos 125(2):179-91.

STOLER, A.B., BURKE, D.J. \& RELYEA, R.A. 2016. Litter chemistry and chemical diversity drive ecosystem processes in forest ponds. Ecology 97(7):1783-95.

ULTSCH, G.R., BRADFORD, D.F. \& FREDA, J. 1999. Physiology coping with the environment. In Tadpoles: The Biology of Anuran Larvae (R.W. McDiarmid \& R. Altig, eds.). University of Chicago Press, Berkeley, p. 189-214.

WELLS, K.D. 2007. The Ecology and Behavior of Amphibians. Chicago, USA: The University of Chicago Press.

ZIMMERMAN, B.L. \& SIMBERLOFF, D. 1996. An historical interpretation of habitat use by frogs in a Central Amazonian forest. J. Biogeogr. 23(1):27-46.

Received: $13 / 10 / 2020$

Revised: 02/07/2021

Accepted: 05/07/2021

Published online: 23/08/2021 